\title{
God as Substance without Substance Ontology
}

\author{
DANIEL VON WACHTER, MUNICH
}

Theists often defend substance ontology. After all, God is supposed to be a substance. In particular, traditional Christian doctrine teaches that God is a substance: the council of Constantinople in 381 declared that God is a substance $(o v \sigma l \alpha)$, more precisely three persons in one substance. Does a theist therefore have to accept substance ontology, as for example Thomas Aquinas did? In this paper I shall spell out the reasons for calling God a substance and argue that theism, nevertheless, does not require substance ontology but is compatible with an alternative ontology which I call stuff ontology.

\section{Substance Ontology}

A classical substance ontology assumes that the world is made up of things each of which belongs to a kind. ${ }^{1}$ More precisely, it assumes that each thing contains a property bearer that is kinded: it is an exemplification of a kind universal, i.e. it is an individual that stands in the relation of exemplification to a certain universal which may have other exemplifications. An exemplification of a kind universal bears properties each of which is an exemplification of a property universal. Further it is a common thesis of classical substance ontology that substances act. They have powers to bring about certain states of affairs. All causation is reduced to agent causation.

My main reason for rejecting substance ontology is that most of the stuff of the universe does not seem to consist of substances. Let me give three reasons for this claim:

First, most things seem to belong to many kinds no single one of which is objectively more important than all others. Substance ontology claims that each thing belongs to one and only one kind in a special way, its substantial kind. That is the one of which the property bearer is an exemplification. It is also the one that is responsible for the conditions of the dia-

${ }^{1}$ Professor Loux explains this in his contribution to this volume; see also Loux 1974 and Loux 1998. 
chronic identity and of the existence of the thing: if it ceases to be a thing of that kind it thereby ceases to exist. So according to substance ontology, one must discover which of the kinds to which the thing belongs is the substantial kind.

The trouble with this is that there does not seem to be such a unique substantial kind of each thing. A particular apple, for example, belongs to many kinds: it is a fruit, an apple, a Golden Delicius, etc. Substance ontology claims that one of these kinds is the thing's ontologically fundamental kind. Usually the lowest kind ('infima species') is taken to be the substantial kind. But there is no lowest kind because for each kind there is a lower one. We can form the concept of a red Golden Delicius, of a red and sour Golden Delicius, etc. These concepts might not be common or practical but there is nothing in the thing which makes such concepts impossible or inadequate. If this is true, then the claim that only one of the kinds to which a thing belongs is ontologically fundamental is false.

Second, substance ontology assumes that the conditions of the diachronic identity of a thing are fixed in the thing. The substantial kind of a thing $A$ also determines under which conditions $A$ ceases to exist and under which conditions something is identical with $A$. But it seems more plausible that the conditions of diachronic identity are fixed not in the thing but in the sortal concept under which the thing is traced. The thing has to have certain properties in order to fall under a concept, but which of the sortal concepts under which a thing falls is used in order to trace it through space and time is your choice. Contra substance ontology, the conditions of diachronic identity are not to be discovered in the thing. For example, take a certain statue made of bronze. You can trace it through space and time as a statue or as a lump of bronze. If you take it as a statue it ceases to exist if it is melted. If you take it as a lump of bronze it does not cease to exist if it is melted. However, substance ontology claims that the bearer of the properties of the thing, e.g. its being five kilograms in mass, is an exemplification of a kind universal, and this determines objectively whether the thing ceases to exist if it is melted.

Third, substance ontology entails that there is one correct way of carving up the world into things. If the yolk of an egg has a density of 1.2 $\mathrm{g} / \mathrm{cm}^{3}$, then there must be a property bearer that is bearing a property which is an exemplification of the corresponding property universal. You might want to say that the egg yolk as well as the whole egg instantiate the universal, but this would mean that the density in one place consists in the universal being exemplified several times. This would be ontological over- 
determination. The substance ontologist should therefore assume that some portions of matter are property bearers and others are not. My objection against this is that the material world does not seem to consist of chunks in this way. On the macro as well as on the micro level we carve up reality into things in various ways none of which is better than all others. The most plausible version of substance ontology claims that the real substances are the particles, but modern physics suggests that the material world does not consist of particles and nothing in between, but rather of fields. Furthermore, it suggests that, unlike substances and unlike 'atoms' as they are traditionally conceived, the particles do not have determinate conditions of diachronic identity. ${ }^{2}$

\section{Stuff Ontology}

Let me sketch an alternative which I call stuff ontology:

- The material world is not partitioned in chunks, any portion of matter can equally well be taken as a thing. Although some portions are more handy than others because they have a stronger causal or functional unity, there is no one ontologically correct way of carving up the material world into things.

- Every portion of matter belongs equally to many kinds, no one of which is the ontologically fundamental one.

- A portion of matter can be traced through time by various sortal concepts, its diachronic identity is therefore relative and subjective.

- Material things do not act but cause states of affairs only through being constituents of states of affairs that cause other states of affairs.

This is a radical departure from classical substance ontology. Stuff ontology denies that material things are substances and that the world consists of substances. I now want to show how theism, nevertheless, is compatible with this ontology and that there is still good reason for calling God a substance. For this I shall list features of God which, according to what philosophers usually mean by a substance, are typical features of substances.

${ }^{2}$ For more arguments against substance ontology see Wachter 2000, ch. 3. 


\section{God is Concrete}

First, on all accounts it is a necessary feature of a substance that it is concrete. By this it is meant that a substance is ontologically complete, as opposed to, for example, a property, such as a particular stone's being seven kilograms in mass. That the stone is concrete means that it includes all its properties and other ontological constituents. (By properties I mean its individual properties, also called 'tropes'.) An abstract entity, such as a property, exists together with other abstract entities within a thing. It depends on them, it cannot exist without them. A concrete entity is independent in the sense that it does not need to exist together with other entities.

God is concrete in this sense, he is not just an aspect or a property of a thing. In particular he is not an aspect or an emergent property or the 'being' of the world. That God is concrete rules out some non-traditional versions of theism, as they are popular among theologians of the last two hundred years. Theologians who say that there is a God but that he is not a person often seem to think of God (as far as they state at all what they mean by 'God') as an inner-worldly aspect of reality. Such a God would not be concrete. Also the God of process theology does not seem to be concrete. ${ }^{3}$

But according to classical theism, as for example assumed by Christianity, God is distinct from the material world as well as from human beings and their mental lives. As he brought about everything besides himself through his action, he is the cause of it all and could exist without it. Only a concrete God can be the cause of the universe and could exist independently of it.

To accept this one does not need to accept classical substance ontology. All you need is a notion of concreteness, which stuff ontology does have. It just uses it less restrictively than substance ontology does, because it takes the complete content of every region of space to be a concrete entity. Thus stuff ontology is compatible with the existence of a concrete, personal God who brought the universe into being and sustains it and could exist on its own.

It is convenient and adequate to use 'substance' in a wide sense so that to be a substance is just to be concrete. According to this usage God clearly is a substance. In any case, to be concrete is a necessary feature of being a substance, and God has this feature.

\footnotetext{
${ }^{3}$ Griffin 2001, 5-7.
} 


\section{God Persists}

Another necessary feature of a substance is that it persists through time. While concreteness is a feature that God shares with material things, I need to assume that God differs from material things in the way he persists through time. According to stuff ontology a material thing can be traced with different sortal concepts through space and time, so its diachronic identity is in a sense relative: if you refer to a thing $A$ at one time and to a thing $B$ at another time, there may be no fact of the matter whether $A$ is identical with $B$. We can also express this by saying that material things do not have determinate conditions of diachronic identity. ${ }^{4}$ For example, it may be nothing to be discovered whether a certain ship is identical with the ship of Theseus. There is no fact of the matter whether the ship of Theseus is identical with the ship rebuilt with the planks of the old ship.

God's diachronic identity (like, I believe, the identity of human beings) is of course in no sense relative. Whenever you refer to God, or to a divine person, at one time there is a fact of the matter whether he is identical with a certain a God referred to at another time. You might find this trivial, but I do not find it trivial because I deny it for material objects. I need to assume that God can create things that do not have absolute diachronic identity and in this respect have a different ontological structure than he has. But there is no problem with this. There is no metaphysical principle according to which if one entity has absolute diachronic identity everything has to have absolute diachronic identity.

According to stuff ontology, material things do not have determinate conditions of diachronic identity, but they are in time. That is why material things can be traced through space and time by sortal concepts or by pointing at them. That is also why they are involved in events which stand in temporal relations to each other.

According to theism as I consider it, God is in time too. He persists through time, as we do, which is a necessary feature of a substance. However, there is also a long tradition in Christian philosophical theology (e.g., Boethius and Thomas Aquinas) of taking God to be outside of time. This view, which is based on the assumption that anything in time is bound to perish, is less compatible with the thesis that God is a substance. A God

\footnotetext{
${ }^{4}$ Lowe 1998, 34.
} 
who is outside time is more like a Platonic entity or like a principle than what philosophers usually call a substance.

There are many claims commonly made about God that seem to imply that God is in time. For example, God is supposed to be the cause of the universe. Causation takes place in time and it involves things persisting in time during which something happens. Entities that are outside time are causally idle. Further, God is supposed to be a person, that is, someone who acts. Actions happen at a time, there is a time before and a time after, and they have effects in time. If God were outside time, that could not be the case. Moreover, God is supposed to be present. He is supposed to be present at particular occasions, and he is supposed to be present everywhere at all times. All this seems to imply that God is in time and that he is a substance persisting in time. It does not entail, however, that he is a classical substance or that classical substance ontology is true. The difficulties here arise for the view that God is outside time, not for the view that he is not a classical substance or that classical substance ontology is false. ${ }^{5}$

\section{God is a Free Agent}

Philosophers who use the term 'substance' at all generally call things that act substances; therefore, another reason for calling God a substance is that he acts. He is supposed to have powers (namely limitless power, power to do anything that is possible). He is supposed to have reasons for actions, for example moral reasons. Moreover, he is a free agent, that is, his actions are not caused by anything else. They originate in him so that he can cause something de novo or ex nihilo.

Some take the ability to act to be a necessary feature of a substance. On this view all causation is reducible to agent causation. But even if this is not assumed, the ability to act is sufficient for being a substance. Properties, principles, or Platonic forms cannot act. The ability to act and to cause something through action presupposes the necessary features of a substance which I have mentioned already: Only something that is concrete can act. Only something that persists in time can act.

Again, this does not entail that classical substance ontology is true or that God is a classical substance. It entails only that God has a mental life, that he persists in time, and that he has powers to act intentionally. The things he creates may have any ontological structure. They may be persons

${ }^{5}$ For the standard arguments for God being in time see Wolterstorff 1975 and Swinburne 1993. Recent contributions to the debate are in Ganssle and Woodruff 2002. 
or not, they may have absolute diachronic identity or not, they may or may not have kinded property bearers, they may or may not be bundles of properties.

We need to distinguish here the theistic concept of God from the Hegelian concept of God as the infinite. If you take God as the infinite you are led to say that there is nothing that is distinct from God. This has led some authors to pantheism. The concept of God as the infinite might have arisen from a confusion: God has infinite power, infinite knowledge, etc.; so he is limitless in this sense. We have to distinguish this from the claim that there is nothing that is distinct from God. According to theism the universe and everything that is created is distinct from God and is caused by God.

\section{Causal Independence}

So far I have given three reasons for taking God to be a substance: God is concrete, he persists in time, and he causes through action. Another feature of substances is described by Professor Loux and by Professor Legenhausen in their contributions: substances have unity and independence. For example, a horse has a strong unity: its body is cohesive and its parts are connected through functional dependencies. Traditional substance ontology tries to capture this by talking of the form and of the substantial kind. But we can describe unity also without these concepts. Furthermore, we can distinguish various kinds and various degrees of unity. Other things being equal, the stronger the unity of a thing, the more reason there is for calling it a substance. Likewise, the more independent something is, the more reason there is for calling it a substance.

Philosophers who do not take every concrete object to be a substance reserve the term 'substance' for entities with a certain kind of unity. The left half of this table, on such a view, is not a substance. Neither is the sum of this table and the book lying on it. The book on its own may count as a substance because its function, depending on the cooperation on its parts, constitutes a unity, the unity of a machine. Also a horse has a functional unity. In a way, the horse's unity is even stronger because its organs cannot be as easily dissembled and reassembled. ${ }^{6}$

God has a very strong unity. First, his properties cannot be separated from each other. Furthermore, he cannot change his properties. For exam-

\footnotetext{
${ }^{6}$ Roman Ingarden, in his Der Streit um die Existenz der Welt (1965, § 43), systematically distinguished between different kinds of unity and analysed the difference between the unity of an organism and the unity of a machine.
} 
ple: His omnipotence depends on his omniscience because if God were not omniscient he would not be omnipotent because to have a power one needs the knowledge how to bring about the state of affairs.

Second, God is not dependent on any concrete parts. A horse is dependent on its organs: they must function and they must be a part of the body, i.e. they must be correctly connected to the other organs.

If there is a God, God is causally independent from the universe and everything contingent. He brought it all into being and nothing can exist without God sustaining it. He is the only thing that is causally dependent on nothing else at all. He could exist without anything else existing. This constitutes a further reason for calling him a substance.

\section{The Trinity}

God's unity is also the reason why in Christian doctrine God is taken to be one substance although there are three divine persons. The unity is first causal. The Father caused the Son and the Father together with the Son caused the Spirit. Secondly, the unity is personal: None of the divine persons would do what any of the others would not have him do. As the three divine persons have access to each others mental life and act this way in unison they can count as one agent and as one substance. ${ }^{7}$

\section{Necessity}

We need to consider another reason why one might deny that God is a substance. God is supposed to be necessary. While, for example, the world could also exist without me and I might never have existed, the world could not exist without God and God could not fail to exist. God, if there is a God, exists necessarily.

Necessary existence is usually attributed only to things that are not substances, for example numbers or Platonic forms. So, is God like these ideal entities and therefore not a substance? For Thomists and others who take God to be outside time it is difficult to deny this, but if God is in time, his necessary existence amounts to something else. A temporal entity exists necessarily if its existence had no beginning (i.e. there was no time when it did not exist) and if it is impossible that it ceases to exist. ${ }^{8}$ This is the case

\footnotetext{
${ }^{7}$ For recent contributions to the philosophical debate about the Trinity, see Davis et al. 1999.

${ }^{8}$ Wachter 2001.
} 
for God, if he exists. His existence is supposed to have no beginning. And he could not cease to exist because he is powerful enough to prevent his abolition, and due to his character it is impossible that he commits suicide. This way his necessary existence and his being a substance are compatible.

I conclude that there are good reasons for calling God a substance, that theism does not require substance ontology, and that theism is compatible with stuff ontology.

\section{REFERENCES}

Davis, S.T., Kendall, D., and O'Collins, G. (eds.) 1999 The Trinity, Oxford: Oxford University Press.

Ganssle, G.E. and Woodruff, D.M. 2002 God and Time: Essays on the Divine Nature, Oxford: Oxford University Press.

Griffin, D.R. 2001 Reenchantment Without Supernaturalism: A Process Philosophy of Religion, Ithaca: Cornell University Press.

Ingarden, R. 1965 Der Streit um die Existenz der Welt II/1: Formalontologie, Tübingen: Niemeyer.

Loux, M.J. 1974 "Kinds and the Dilemma of Individuation", Review of Metaphysics, 27, 773-784.

- 1998 Metaphysics: A Contemporary Introduction, London: Routledge.

Lowe, E.J. 1998 The Possibility of Metaphysics: Substance, Identity, and Time, Oxford: Clarendon Press.

Swinburne, R. 1993 “God and Time”, in E. Stump (ed.), Reasoned Faith, Ithaca: Cornell University Press, 204-222.

Von Wachter, D. 2000 Dinge und Eigenschaften: Versuch zur Ontologie, Dettelbach: Verlag J.H. Röll.

- 2001 "Die Notwendigkeit der Existenz Gottes", Metaphysica, 2, 55-81.

Wolterstorff, N. 1975, "God Everlasting", in C. J. S. Orlebeke and L. Smedes (eds.), God and the Good: Essays in Honor of Henry Stob, Grand Rapids: Eerdmans Publishing Company. 
